\title{
Comment
}

\section{The Governance of Big Science: On the Wisdom of Solomon}

\author{
STEVE FULLER University of Durham
}

Although Miriam Solomon does not believe that Big Science has moved us into a "post-epistemic" world just yet, she nevertheless recognizes that science is not as permeable to critical scrutiny as it should be. That Solomon is willing to offer some prescriptions to remedy the situation can only be welcomed-and encouraged in others who avow a "naturalistic" approach to epistemology and the philosophy of science. However, Solomon argues that, in at least one major respect, I overestimate the epistemic significance of science's change in scale. Contrary to what I seem to suggest about modes of inquiry in the seventeenth century (and earlier), science never lived up to the epistemic norms proposed by philosophers. Little science was just as beset by interests and other "external" factors as Big Science is today. In response, let me refocus Solomon's point, lest we lapse into a normative relativism that sees the sins of Little Science on par with those of Big Science.

It is a mistake (the fallacy of division) to think that if the norms of critical inquiry are supposed to govern a scientific community, they therefore must be supposed to govern the actions of each individual in that community. On the contrary, the idea of epistemic norms presupposes that individual inquirers are biased and limited. The norms, then, are correctives to these natural tendencies. The basic question posed in my paper is under what social conditions are the desired correctives enforceable. Norms are not worth their salt if a community is either unwilling or unable to enforce them. Consider the social condition described in Hull (1988), whereby reliable knowledge of systematic zoology emerges from the sublimation of interpersonal conflicts in the peer review process. This is a misleading indicator of the possibilities for critical inquiry in the Age of Big Science, not because Hull's zoologists were relentlessly self-interested (though they were), but because they constituted such a small portion of the systematic zoology community. The lesson that I take from Hull is that mutual criticism has become a luxury afforded to a few elite practitioners-and only when a discipline is in a certain phase of its development. The norms of criticism would seem to have little purchase beyond that elite group at those select moments. As science has become bigger, and scientists have become more stratified, the work of the vast majority of inquirers is simply ignored even when published (see Cole 1992, for recent evidence).

And while it is true that scientistsbeing only human - have always tried to violate the norms in the service of their own interests, violations were easier to catch in the seventeenth century because others would be literally witnessing one's (verbal or experimental) demonstrations. The growth of the scientific enterprise subsequently fragmented and specialized this public space, with inquirers coming to evaluate each other's work at a distance, through what Steven Shapin calls "virtual witnessing," namely, by assessing the plau- 
sibility of a published account of a scientific event. The cost-benefit ratio of seeking out error in a colleague's work - say, by reproducing her experiment in one's own lab-has become too high for most inquirers to bear. To keep pace with the rhythm of the knowledge system, the inquirer must, without any display of reasoning, either incorporate or ignore a piece of research-a far cry from the days of explicitly arguing for or against the claims made in that research. Moreover, contra Solomon, contemporary investigations into research fraud do not constitute critical inquiry in the relevant sense because they are conducted, not as part of the scientific routine, but only after a politically sensitive constituency is shown to be the potential recipient of such fraud.

My point, then, is not that Big Science is disrupted by too many outside interests to be a truly epistemic enterprise. Rather, I am arguing that the social structure internal to science itself inhibits the enforcement of the norms of critical inquiry. Big Science is a house divided against itself.

Solomon observes that her own prescriptions to the scientific community really aim to improve scientific accountability, not scientific research per se. The same, she believes, is true of my own normative proposals, notwithstanding my apparent failure to see the difference between the moral and epistemic dimensions of science. It is clear from the tenor of Solomon's remarks that she sees the normative epistemologist in the position of giving the public its due without letting public scrutiny interrupt the day-to-day workings of science. However, in order to claim that nonexperts criticize science "from a position of relative ignorance" vis-a-vis expert scientists, Solomon must assume that the ends of scientific inquiry remain constant. Experts know the best way to do science, only once agreement has been reached on what sort of science should be done. Once the ends are fixed, the course of inquiry toward those ends can be charted in terms of methodological standards, in terms of which the performance of particular inquirers can then be evaluated. Science seems relatively autonomous-and scientists relatively superior - to the rest of society, only if questions about the ends of science are not raised too often. However, I do not see the philosopher as under any obligation to respect this convention.

\section{References}

Cole, S. (1992) Making Science. Cambridge, MA: Harvard University Press.

Hull, D. (1988) Science as a Process. Chicago: University of Chicago Press.
STEVE FULLER

DEPARTMENT OF SOCIOLOGY

UNIVERSITY OF DURHAM

DURHAM DHI 3IT, UK 